\title{
Occurrence of gastrointestinal parasites in goat kids
}

\author{
Ocorrência de parasitos gastrintestinais em cabritos \\ Willian Marinho Dourado Coelho ${ }^{1 *}$; Alessandro Francisco Talamini do Amarante ${ }^{2}$ Katia Denise Saraiva Bresciani ${ }^{3}$ \\ ${ }^{1}$ Department of Preventive Veterinary Medicine, School of Veterinary and Agrarian Sciences, \\ Universidade Estadual Paulista - UNESP \\ ${ }^{2}$ Institute of Biosciences, Universidade Estadual Paulista - UNESP \\ ${ }^{3}$ Department of Animal Support, Production and Health, Universidade Estadual Paulista - UNESP
}

Received February 24, 2011

Accepted September 27, 2011

\begin{abstract}
Fecal samples from male and female goat kids, of different breeds and up to one year of age, were analyzed to determine egg and oocyst counts per gram of feces (EPG and OPG, respectively), and fecal culturing was performed to identify nematode genera. Helminth eggs and Eimeria spp. oocysts were found in 93.06\% (188/202) and 77.22\% (156/202) of the fecal samples, respectively. From fecal cultures, the following genera were identified: Cooperia in 11.88\% (24/202), Haemonchus in 51.98\% (105/202), Oesophagostomum in 9.4\% (19/202), Strongyloides in $5.94(12 / 202)$ and Trichostrongylus in $20.79 \%(42 / 202)$ of the samples. The Eimeria species found were E. alijevi in $25.24 \%(51 / 202)$, E. arloingi in $7.42 \%$ (15/202), E. caprina in $2.97 \%$ (6/202), E. caprovina in $10.39 \%(21 / 202)$, E. christenseni in $4.45 \%$ (9/202), E. joklchijevi in $11.38 \%$ (23/202), E. hirci in 9.4\% (19/202) and E. ninakoblyakimovae in $28.71 \%(58 / 202)$ samples. Among the gastrointestinal parasites, the genus Haemonchus and two Eimeria species (E. ninakohlyakimovae and $E$. alijevi) were predominants.
\end{abstract}

Keywords: Goats, fecal culture, Eimeria spp., Haemonchus spp.

\section{Resumo}

Amostras fecais de cabritos machos e fêmeas, de diferentes raças e com até uma ano de idade, foram examinadas para determinaçáo do número de ovos e oocistos por grama de fezes (OPG e OoPG, respectivamente) e coprocultura para identificação genérica dos nematódeos. Ovos de helmintos e oocistos de Eimeria spp. foram observados em $93,06 \%(188 / 202)$ e $77,22 \%(156 / 202)$ das amostras, respectivamente. Pelas coproculturas, foram identificados os gêneros Cooperia em 11,88\% (24/202), Haemonchus em 51,98\% (105/202), Oesophagostomum em 9,4\% (19/202), Strongyloides em 5,94 (12/202) e Trichostrongylus em 20,79\% (42/202) das amostras. As espécies de Eimeria encontradas foram $E$. alijevi em 25,24\% (51/202), E. arloingi em 7,42\% (15/202), E. caprina em 2,97\% (6/202), E. caprovina em 10,39\% (21/202), E. christenseni em 4,45\% (9/202), E. joklchijevi em 11,38\% (23/202), E. hirci em 9,4\% (19/202) e E. ninakohlyakimovae em 28,71\% (58/202) das amostras. Dentre os parasitas gastrintestinais, houve predominância do gênero Haemonchus e de duas espécies de Eimeria: E. ninakohlyakimovae e E. alijevi.

Palavras-chave: Caprinos, Coprocultura, Eimeria spp., Haemonchus spp.

\section{Introduction}

Gastrointestinal parasitic infections in goats are one of the main factors limiting the expansion of this sector in Brazil (COSTA et al., 2009) and worldwide (GITHIGIA et al., 2001), and lead to great economic losses (COELHO, 2009).

\footnotetext{
${ }^{*}$ Corresponding author: Willian Marinho Dourado Coelho

Department of Preventive Veterinary Medicine, School of Veterinary and

Agrarian Sciences, Universidade Estadual Paulista - UNESP,

Via de Acesso Prof. Paulo Donato Castellane, sn,

CEP 14884-900, Jaboticabal, São Paulo, Brazil

e-mail: willianmarinho@hotmail.com

Financial support: São Paulo State Research Foundation - FAPESP
}

The aim of this study was to determine occurrences of gastrointestinal parasites in goat kids from farms in the Brazilian states of São Paulo, Mato Grosso do Sul, Goiás and Minas Gerais.

Fecal samples were collected directly from the rectums of 202 goats, during the mornings, between March 2009 and November 2010. The groups were constituted of male and female animals, of different breeds and up to one year of age. EPG (helminth egg counts per gram of feces) and OPG (oocyst counts per gram of feces) were measured in accordance with the modified technique of Gordon and Whitlock (1939), and samples 
Table 1. Mean OPG and EPG values from 202 goats from different Brazilian states between 2009 and 2010.

\begin{tabular}{|c|c|c|c|c|c|}
\hline \multirow[t]{2}{*}{ Brazilian States } & \multirow{2}{*}{$\begin{array}{c}\text { OPG } \\
\text { Eimeria }\end{array}$} & \multicolumn{4}{|c|}{ EPG } \\
\hline & & Moniezia & Strongyloides & Strongylida & Trichuris \\
\hline Goiás $(\mathrm{n}=31)$ & 1141.03 & 223.50 & 602.44 & 1527.91 & 22.25 \\
\hline Mato Grosso do Sul $(\mathrm{n}=52)$ & 1040.20 & 70.52 & 350.75 & 874.15 & 47.33 \\
\hline Minas Gerais $(\mathrm{n}=27)$ & 627.45 & 20.70 & 125.83 & 704.20 & 5.35 \\
\hline São Paulo $(\mathrm{n}=92)$ & 1833.30 & 115.25 & 770.44 & 2288.48 & 33.17 \\
\hline
\end{tabular}

$\mathrm{OPG}=$ oocysts per gram of feces. $\mathrm{EPG}=$ eggs per gram of feces.

Table 2. Frequencies and absolute values for species of the genus Eimeria from 202 goat kids from different Brazilian states between 2009 and 2010 .

\begin{tabular}{|c|c|c|c|c|c|}
\hline Species & Goiás $(n=31)$ & Mato Grosso do Sul $(n=52)$ & Minas Gerais $(n=27)$ & Sáo Paulo $(\mathrm{n}=92)$ & Total \\
\hline E. alijevi & $19.6 \%(10 / 51)$ & $43.13 \%(22 / 51)$ & $13.72 \%(7 / 51)$ & $23.52 \%(12 / 51)$ & $25.24 \%(51 / 202)$ \\
\hline E. arloingi & $20 \%(3 / 15)$ & $33.33 \%(5 / 15)$ & $0.0 \%(0 / 15)$ & $46.66 \%(7 / 15)$ & $7.42 \%(15 / 202)$ \\
\hline E. caprina & $0.0 \%(0 / 6)$ & $33.33 \%(2 / 6)$ & $0.0 \%(0 / 6)$ & $66.66 \%(4 / 6)$ & $2.97 \%(6 / 202)$ \\
\hline E. caprovina & $19.04 \%(4 / 21)$ & $19.04 \%(4 / 21)$ & $33.33 \%(7 / 21)$ & $28.57 \%(6 / 21)$ & $10.39 \%(21 / 202)$ \\
\hline E. christenseni & $0.0 \%(0 / 9)$ & $22.22 \%(2 / 9)$ & $22.22 \%(2 / 9)$ & $55.55 \%(5 / 9)$ & $4.45 \%(9 / 202)$ \\
\hline E. joklchijevi & $13.04 \%(3 / 23)$ & $34.78 \%(8 / 23)$ & $0.0 \%(0 / 23)$ & $52.17 \%(12 / 23)$ & $11.38 \%(23 / 202)$ \\
\hline E. hirci & $15.78 \%(3 / 19)$ & $31.57 \%(6 / 19)$ & $10.52 \%(2 / 19)$ & $42.10 \%(8 / 19)$ & $9.4 \%(19 / 202)$ \\
\hline E. ninakohlyakimovae & $13.79 \%(8 / 58)$ & $31.03 \%(18 / 58)$ & $8.62 \%(5 / 58)$ & $46.55 \%(27 / 58)$ & $28.71 \%(58 / 202)$ \\
\hline
\end{tabular}

with EPG values greater than 500 were subjected to fecal culturing using the technique of Roberts and O'Sullivan (1950), followed by identification of third-stage larvae (L3) as described by Ueno and Gonçalves (1998).

Samples positive for Eimeria spp. were subjected to oocyst sporulation in Petri dishes using a mixture of aqueous solution of sieved feces and $2.5 \%$ potassium dichromate $(1: 1)$ at room temperature for up to 10 days (VIEIRA et al., 1997). Subsequently, the oocysts were concentrated in saturated sugar solution (SHEATHER, 1923) and morphometrically classified (LEVINE, 1982) using a $10 \times$ widefield micrometer eyepiece (Bioval $\left.{ }^{\circ}\right)$ with 40 and 100-fold magnification.

Helminth eggs and Eimeria spp. oocysts were found in $93.06 \%$ $(188 / 202)$ and $77.22 \%(156 / 202)$ of the fecal samples, respectively. Only 19.8\% (40/202) of the animals showed EPG counts of up to 500 (Table 1). EPG counts lower than those obtained in the present study were reported by Hassum (2008) among goats younger than two years of age in the state of Rio Grande do Sul, where the peak egg count was 517 EPG. There was a statistically significant association $(\mathrm{P}<0.0005)$ between $\mathrm{EPG}$ values and stool consistency, such that animals with high EPG presented abnormal consistency. Animals aged less than 90 days $(\mathrm{P}<0.03)$ also showed higher values. Gender and breed did not have any influence on occurrences of parasites $(\mathrm{P}>0.05)$.

The genera of Strongylida, with their respective percentage occurrences in fecal cultures, were the following: Cooperia (11.80\%), Haemonchus (57.14\%), Oesophagostomum (9.31\%) and Trichostrongylus (21.73\%). The Eimeria species found were E. alijevi, E. arloingi, E. caprina, E. caprovina, E. christenseni, E. joklchijevi, E. hirci and E. ninakohlyakimovae (Table 2).

Among the helminths found in our study, the genus Haemonchus was the most prevalent, since it was recorded in 51.98\% (105/202) of the animals. This result was equally obtained by Brito et al.
(2009) in Maranhão. Differently, Martins Filho and Menezes (2001) stated that the genus Oesophagostomun constituted the most prevalent helminth in goats in Paraíba. The low occurrence of Trichuris in our study was similar to that reported by Bavia et al. (1982) among goats in Bahia.

The species $E$. ninakohlyakimovae and $E$. alijevi had higher prevalence and were found in $28.71 \%(58 / 202)$ and $25.24 \%(51 / 202)$ of the goats, respectively. Predominance of E. ninakohlyakimovae was reported by Ahid et al. (2009). Differently from our results, Tembue et al. (2009) in Pernambuco found higher occurrences of $E$. arloingi among goats.

Parasitism by helminths of the genus Haemonchus (SILVA et al., 2008) and protozoa belonging to the genus Eimeria, especially the species E. ninakohlyakimovae (FREITAS et al., 2005), may lead to significant economic losses from goat breeding, since these parasites are highly pathogenic and cause intense morbidity and mortality in the herd (BRITO et al., 2009). Therefore, more attention should be paid to prophylaxis against such parasites, because high EPG and OPG values have been found in goats from the different regions analyzed, with high prevalence of the genus Haemonchus and the Eimeria species E. ninakohlyakimovae and E. alijevi.

\section{References}

Ahid SMM, Medeiros VMC, Bezerra ACDS, Maia MB, De Lima VXM, Vieira LS. Espécies do gênero Eimeria Schneider, 1875 (Apicomplexa: Eimeriidae) em pequenos ruminantes na mesorregião Oeste do Estado do Rio Grande do Norte, Brasil. Ciênc Anim Bras 2009; 10(3): 984-989.

Bavia ME, Caldas EM, Fiterman IR. Distribuição da freqüência de helmintos e protozoários em ovinos e caprinos das regióes de Quinjibe, Euclides da Cunha e Monte Santo-Bahia. Arq Esc Med Vet 1982; 7(1): 121-130. 
Brito DRB, Santos ACG, Teixeira WC, Guerra RMSNC. Parasitos gastrintestinais em caprinos e ovinos da microrregiáo do alto Mearim e Grajaú, no estado do Maranhão, Brasil. Ciênc Anim Bras 2009; 10(3): 967-974.

Coelho WAC. Resistência anti-helmintica em caprinos no municipio de Mossoró-RN, Rio Grande do Norte-Brasil [Dissertação]. Rio Grande do Norte: Universidade Federal Rural do Semi-Árido, Rio Grande do Norte; 2009.

Costa VMM, Simões SVD, Riet-Correa F. Doenças parasitárias em ruminantes do Semi-Árido brasileiro. Pesq Vet Bras 2009; 29(7): 563-568.

Freitas FLC, Almeida KS, Nascimento AA, Machado CR, Veschi JLA, Machado RZ. Espécies do gênero Eimeria Schneider, 1875 (Apicomplexa: Eimeriidae) em caprinos leiteiros mantidos em sistema intensivo na região de São José do Rio Preto, estado de São Paulo, Brasil. Rev Bras Parasitol Vet 2005; 14(1): 7-10.

Githigia SM, Thamsborg SM, Munyua WK, Maingi N. Impact of gastrintestinal helminths on production in goats in Kenia. Small Rum Res 2001; 42(1): 21-29. http://dx.doi.org/10.1016/S09214488(01)00240-1

Gordon HM, Whitlock HV. A new technique for counting nematode eggs in sheep faeces. J Counc Sci Ind Res 1939; 12(1): 50-52.

Hassum IC. Ocorrência de parasitismo por nematóides gastrintestinais em caprinos e ovinos oriundos de duas propriedades rurais no distrito de Palmas, BagélRS: dados preliminares. Bagé: EMBRAPA; 2008. 14 p. (Embrapa Pecuária Sul, Documentos, n. 80).
Levine ND. Taxonomy and life cycles of coccidia. In: Long PL. The biology of the Coccidia. Baltimore: University Park Press; 1982. p.1-33.

Martins Filho E, Menezes RCAA. Parasitos gastrintestinais em caprinos (Capra hircus) de uma criação extensiva na microrregião de Curimataú, Estado da Paraíba, Brasil. Rev Bras Parasitol Vet 2001; 10(1): 41-44.

Roberts FHS, O'Sullivan JP. Methods for egg counts and larval cultures for strongyles infesting the gastrointestinal tract of cattle. Aust J Agri Res 1950; 1(1): 99-102. http://dx.doi.org/10.1071/AR9500099

Sheather AL. The detection of intestinal protozoa and mange parasites by a flotation technique. J Comp Pathol 1923; 36: 266-275.

Silva CAS, Silva MLCR, Nóbrega GH, Paranhos GM, Lôbo KMS, Athayde ACR. Estudo comparativo da carga parasitária e hematócrito em caprinos (Capra hircus L.) abatidos em matadouro público. ACSA 2008; 4(1): 1-6.

Tembue AASM, Ramos RAN, Lima MM, Faustino MAG, Meunier IMJ, Alves LC. Espécies do gênero Eimeria Schneider, 1875 (Apicompexa: Eimeriidae) em pequenos ruminantes, provenientes do Município de Ibimirim, Estado de Pernambuco. Vet Not 2009; 15(2): 51-57.

Ueno H, Gonçalves PC. Manual para diagnóstico das helmintoses de ruminantes. Tóquio: JICA; 1998.

Vieira LS, Cavalcante ACR, Ximenes LJF. Epidemiologia e controle das principais parasitoses de caprinos nas regióes semi-áridas do Nordeste. Sobral: Embrapa-CNPC; 1997. 